\title{
Behavioral Issues in Price Setting in Business-to-Business Marketing: A Framework for Analysis
}

\author{
Gopalkrishnan R. Iyer ${ }^{1}$ \\ Professor of Marketing \\ College of Business \\ Florida Atlantic University \\ 777 Glades Road \\ Boca Raton, FL 33431 \\ USA \\ Phone: 561-297-0917 \\ E-mail: giyer@fau.edu
}

\author{
Sarah Xiao \\ Lecturer in Marketing \\ Durham University Business School \\ Durham, DH1 3LB, UK \\ Tel: +44 (0)191334 5317 \\ E-Mail: hong.xiao@durham.ac.uk \\ Arun Sharma \\ Professor of Marketing \\ Department of Marketing \\ University of Miami \\ P.O. Box 248147 \\ Coral Gables, FL 33124 \\ USA \\ Phone: 305-284-1770 \\ E-Mail: asharma@miami.edu \\ Michael Nicholson \\ Professorial Teaching Fellow \\ Durham University Business School \\ Durham, DH1 3LB, UK \\ Tel: +44 (0)191334 5402 \\ E-Mail: Mike.nicholson@durham.ac.uk
}

Cite as:

Iyer, G.R. et al., Behavioral issues in price setting in business-to-business marketing: A framework for analysis, Industrial Marketing Management (2015), http://dx.doi.org/10.1016/j.indmarman.2015.02.001

${ }^{1}$ Corresponding Author 


\section{Highlights}

- Managerial price setting processes are examined through insights obtained from behavioral decision making.

- Behavioral models of pricing provide realistic understanding of managerial price setting in business-to-business contexts.

- Issue understanding, cognitive biases and heuristics are offered as major managerial factors that impact price setting.

- An agenda for future research is offered along with managerial suggestions for price setting. 


\title{
Behavioral Issues in Price Setting in Business-to-Business Marketing: A Framework for Analysis
}

\begin{abstract}
Business-to-business pricing research has often focused on developing rational and normative frameworks and models for pricing issues, strategies and tactics. However, there has been less attention given to behavioral models that help us understand the realities of pricing and how managers actually set prices. Specifically, there has been less attention given to the various individual and group influences on the price setting process. We apply insights from a steadily increasing body of literature on behavioral decision making to identify some relevant behavioral issues that may affect managerial price setting processes in business-to-business contexts. We conclude with some implications for theory building and practice and an agenda for future research.
\end{abstract}

Keywords: Business-to-business Pricing; Price Setting; Industrial Pricing Decisions; Behavioral Bias in Pricing 
Research on pricing in business-to-business markets is sparse, though some recent articles have shed light on various aspects of pricing, including supply chain pricing (Voeth and Herbst 2006), price planning (Lancioni 2005b), pricing in international markets (Forman and Hunt 2005), and pricing of integrated solutions (Sharma and Iyer 2011). In addition, recent research has also called attention to the study of value-based pricing (Hinterhuber 2004) as well as the need to understand the impacts and influences of key managers (Lancioni, Schau and Smith 2005), including the CEO (Liozu and Hinterhuber 2013), on price setting.

While normative frameworks have been suggested in the past for price setting in business-to-business contexts, research has also suggested that managers take decisions that appear to deviate from what could be considered optimal given the application of these frameworks (Kopalle, Mela and Marsh 1999; Liozu 2013; Urbany 2001). However, what is "optimal" can only be determined from the idiosyncratic environmental and organizational context of the firm as well as the firm's intended pricing objectives. Moreover, while there is some research in organizational buying behavior that contends that individual managers' interpretations and cognitive processes affect purchasing decisions (Barclay and Bunn 2006; Wilson, McMurrian and Woodside 2001), similar research on pricing in industrial markets is only in its infancy. For example, Lancioni et al. (2005) demonstrate that managers often face internal "roadblocks" from within their organizations in the price setting process. On the other hand, Liozu and Hinterhuber (2013) find from their empirical study that CEO championing of pricing activities actually enhances the firm's pricing capabilities and contributes to better firm performance.

Approaching the field of business-to-business pricing from the perspective of behavioral decision making, which contends that managerial cognitive biases are key sources for deviations 
from optimal decisions, we attempt to understand the impacts of managerial factors on the price setting process. Our primary objective is to build a case for the study of managerial cognitions that could affect the use and application of normative frameworks of price setting. With this objective in mind, we attempt to make three distinct contributions to the current sparse research in the area of managerial influences on business-to-business pricing. First, we extend insights from behavioral research from various disciplines, including behavioral economics, management and behavioral finance, to understand how behavioral issues may contribute to the price setting process. While most existing research on business-to-business marketing focuses on the customer or the purchasing manager (e.g., Anderson et al. 2000), we place our attention on the manager in the selling or marketing firm. Second, we offer a preliminary framework that contends that managerial issue identification, cognitive biases and heuristics intervene in the price setting process, specifically in the observed outcomes of normative decision frameworks. Prior literature on price setting has shown that managers often use pricing objectives that may not be appropriate given the environmental and organizational context (Carricano 2014; Griffith and Rust 1997). Also, managers may rely too much on one method of pricing (e.g., the cost-plus method), while ignoring other methods (Nagle, Hogan and Zale 2010). Moreover, they may not view pricing as a dynamic strategy that needs to be altered with response to changing contexts (Monroe and Cox 2001). Finally, given the paucity of behavioral as well as prescriptive research on price-setting in business-to-business marketing, we offer some implications for theory as well as an agenda for future academic research that would enhance our understanding of how managers set prices. In this context, we also offer suggestions and implications that could result in enhanced managerial decision competence and thus, improvements in the price setting process in business-to-business markets. 
The rest of this paper is organized as follows. In the next section, we take stock of current research in business-to-business marketing, in general, and pricing in particular, and call attention to understanding managerial factors that could impact the price setting process. We then selectively review the literature on behavioral decision making from various disciplines and identify some factors that may impact price setting in business-to-business markets. We then offer some implications for theory and practice as well as an agenda for future research.

\section{Understanding Managers' Impacts on the Price Setting Process}

Scholars have proposed several rational and normative frameworks for decision making with respect to prices (see, for examples, Morris and Calantone 1990; Noble and Gruca 1999; Oxenfeldt 1973; Tellis 1986). Such a normative focus is indeed warranted given that pricing is often viewed by managers in tactical rather strategic terms (Dutta et al. 2002), and most managers are daunted by the complexities of developing elaborate pricing plans for their products (Lancioni 2005b). However, at the same time, researchers are aware that most firms do not always make the correct strategic decisions and in the context of pricing, these could have severe financial implications for the firm (Cudahy and Coleman 2007; Hinterhuber 2004; Sharma and Iyer 2011). In fact, a recent survey revealed that $70 \%$ of executives do not believe that their firms have clear pricing strategies (Accenture 2011). Baker, Marn and Zawada (2010a) suggest that most firms do not invest in pricing infrastructure and for a Global 1200 company, a one-percent improvement in average prices of services and goods could lead to an $8.7 \%$ increase in operating profits.

Researchers have also uncovered that managerial price setting suffers from various issues ranging from selection of inappropriate objectives to misunderstandings of the concept of value 
and how it relates to price (Hinterhuber 2004; Hogan and Lucke 2006; Morris and Calantone 1990). Moreover, significant opportunities are lost given that even marginal increases in prices could yield significantly more profits as compared to other strategic or tactical actions (Hinterhuber 2004). Apart from a failure to adjust prices to account for changes in industry demand when pricing through a product's lifecycle (Baker, et al. 2010b), significant concerns arise when companies set prices lower than what the market could pay (Eugster, Kakkar and Roegner 2000). This is because low prices contribute to lost opportunity and in markets that are often inelastic, represent errors that do not, even fortuitously, translate into increased sales. Indeed, there is considerable evidence from practice that errors in pricing may have serious consequences for the organization (Baker, Marn and Zawada 2010b; Eugster, Kakkar and Roegner 2000; Johansson, Krishnamurthy and Schlissberg 2003; Krishnamurthy, Johansson and Schlissberg 2003).

Research on pricing in business-to-business marketing had been traditionally inspired by approaches within economics. The primary assumptions are that customers (or, purchasing firm's representatives) use a rational calculus in responding to prices and that marketing firms set their prices rationally with a view to cover costs and achieve broader firm-level objectives. The rational behavior hypothesis has largely remained unchallenged, even though the discrepancies between economic theory and pricing practices have been highlighted in the past (e.g., Hall and Hitch 1939). In fact, most academic approaches to pricing are either descriptive studies of pricing practices or normative frameworks offering prescriptions on rational price-setting behaviors. What is lacking is a cumulative understanding of the price setting practices followed by firms and the factors that contribute to successful practices (Ingenbleek 2007). 
Since buying decisions in business-to-business markets are taken within an organizational context, it made sense to assume that firms behaved rationally to maximize their own firms' objectives and that the individual decision makers' preferences and tastes mattered very little, given the pursuit of organizational objectives. Similarly, normative models for developing pricing in the business-to-business marketing context are motivated by the premise that marketing firms set their prices rationally with respect to some clear and coherent objectives and after due analysis of the context and circumstances.

Thus, pricing research in business markets has largely ignored the role of the individual manager in pricing decisions and the idiosyncratic impacts they may have on the price setting process. This is in sharp contrast to other areas of business-to-business marketing, most notably organizational buying decisions, where the roles and impacts of individuals and groups are explicitly considered. For example, even the earliest comprehensive frameworks of organizational buying, such as those offered by Robinson, Faris and Wind (1967), Webster and Wind (1972) and Sheth (1973) explicitly considered the fact that the purchasing manager as well as informal groups within the organization, such as the buying center, played a part in organizational buying decisions. Later research and frameworks have also explicitly recognized the role of buying center groups in various aspects of organizational buying decisions (e.g., Bellizzi 1979; Johnston and Lewin 1996; Kauffman 1996; Kohli 1989). In contrast to strictly rational economic frameworks, these models consider multiple influences on organizational buying. More specifically, they include individual influences on organizational buying calling specific attention to the organizational buyer's personal values and needs, as in the Webster and Wind (1972) model, and to the buyer's psychological world, as in the Sheth (1973) model. 
Webster and Wind (1972) acknowledged that organizational buying may be affected by factors that are not strictly rational and economic. They labeled these influences as "nontask" factors and considered a variety of individual, social, organizational and environmental forces that affected otherwise rational economic organizational buying decisions. In Sheth's (1973) model, expectations and background, among other factors such as differences in information sources, search behaviors, perceptual distortion and satisfaction with past purchases were posited to influence decisions makers in industrial buying. Both these models consider and incorporate deviations from rational economic processes in their accounts of organizational buying.

Apart from the vast body of research on buying centers, there is also research within organizational buying literature on the influence of individual managers on the buying processes and decisions. While some research focuses on the demographics of managers, including their education, experience and position within the organization, there is also explicit recognition of the fact that individual managers may use different decision rules for evaluations, or may frame the decision context differently (Crow and Lindquist 1982; Qualls and Puto 1989). Moreover, individual managers may vary in their risk perceptions and how they manage such risks (Hawes and Barnhouse 1987; Kauffman 1996; Puto, Patton and King 1985). An early review of the organizational buying research also revealed individual managers' personality and motivation have been topics of research on the buying process (Johnston and Lewin 1996).

More recently, organizational buying research has also focused on subjective evaluations by individual managers and buying centers (Brown et al. 2011; Brown et al. 2012). Specifically, research on perceptions of the business-to-business brands suggest that brand cues are evaluated by buyers through use of subjective information as well (Brown et al. 2012). Thus, this research stream explicitly calls attention to the decision heuristics used by managers and contends that 
overtly "rational" approaches to organizational buying have not allowed for the examination of subjective judgments in organizational buying (Barclay and Bunn 2006; Brown et al. 2011; Brown et al. 2012).

Such an examination of group and individual factors are largely lacking in research on pricing in business markets. There may be several reasons for this neglect in pricing research. First, even though buying centers are often informal and vary according to the buying decision, managers responsible for the purchasing function can be recognized from their position titles and from organizational charts. In contrast, the responsibility for the pricing function is not so readily discerned; it could reside with divisional managers, product managers, inter-departmental teams or may even be a C-suite decision. Second, while much of organizational buying research is conducted using actual organizational participants as respondents and informants and can be identified from organized sampling frames, large-scale empirical survey research on pricing is often conducted among experienced MBA and executive education students (see for example, Forman and Hunt 2013; Hunt and Forman 2006; Morris and Schurink 1993, while some exceptions are studies in the European context in the decades prior reviewed by Ingenbleek 2007). The lack of availability of ready populations for sampling restricts study of pricing decisions and behaviors to specific questions and also, more often than not, insights are often drawn from case studies and small sample qualitative research. What is lacking is a cumulative understanding of pricing practices from a wider variety of studies (Ingenbleek 2007). Finally, it is possible that the conceptualization of organizations as rational entities may be pervading most of pricing research and may also be restricting researchers to include only objective information sources rather than pricing executives' subjective evaluations in their models. 
However, a growing body of literature now suggests that managers may not follow a rational calculus (Ariely 2009; Urbany 2001) and do make pricing errors, some of them egregious enough to threaten the firm's financial stability. Part of the reason could be that pricing decisions may rely on easily understood or simplistic cost-plus or competitive parity pricing methods, while cognitive complexity may be devoted to other organizational decisions such as product design and development, sales, and promotion. Also, a strong cost focus often permeates the firm (Smith 1995), given that pricing decisions may be embedded across both marketing and accounting/finance departments or subject to scrutiny and review by trained accountants within the firm. Managerial discretion, when available, manifests itself only as deviations from the list price through discounts and rebates. Even here, costs are often the primary consideration. For example, a salesperson may be authorized to not give more than say, a five-percent discount, often estimated from the margin loss the firm could bear for business development and/or additional sales. On the other hand, empirical research indicates that delegation of pricing authority to the salesforce results in superior firm performance, especially under conditions when salespeople possess better market and customer information as compared to managers placed further from the decision contexts (Frenzen et al. 2010).

Over the years, research with business-to-business marketing has developed and offered pragmatic frameworks and tools for managers (see for example, Anderson et al. 2000; Lancioni 2005b; Morris and Calantone 1990). In general, it is offered that systematic pricing plans would enable managers to avoid errors in their pricing decisions. Marketing, in general, appears to have discarded profit maximization objectives through pricing and instead, entreats the consideration of several diverse objectives (Morris and Calantone 1990; Oxenfeldt 1973; Skouras et al. 2005), such as pricing to achieve target unit sales, revenues and market share. 
Similarly, when it comes to selecting a pricing method, an array of different techniques and approaches are offered from which managers could choose, with choice of the "best" method itself contingent on specific objectives and customer, market and industry factors, among other considerations (Anderson et al. 2000; Noble and Gruca 1999).

We contend that a focus on the various behavioral issues that contribute to deviations from standard economic theory as well as to irrational pricing behaviors would lead to a more realistic conceptualization of the price setting process. In addition, such an explicit acknowledgment of irrationality would enable the development of frameworks and schemas that would help reduce serious errors in pricing that may detract from firm performance or even threaten its survival. In the next section, we offer a framework that would contribute to understanding the behavioral issues in pricing.

\section{Understanding Behavioral Issues in the Pricing Process: Towards a Framework}

As argued earlier, our understanding of ways prices are actually set by firms would not only enable the development of better normative frameworks for pricing but also enable researchers to propose models and frameworks that are more realistic. Rational and normative pricing models are often structured as conditional if-then logical statements. In such models, there is little scope for roles played by managerial discretionary decision making. In reality, however, pricing decisions, even though aided by decision models, are the purview of specific individuals and groups in the organization. Despite similarities in contexts and availability of decision making models, pricing decisions may suffer from unwarranted risk avoidance (Guiltinan 1976; Hunt and Forman 2006), inappropriateness of chosen objectives (Smith 1995), perceptions of lack of decision making control (Hinterhuber 2004; Lancioni 2005a), inflexibility 
in decisions (Monroe and Cox 2001), and lack of knowledge of sophisticated methods (Morris and Morris 1990).

The impetus for the study of managerial impacts on organizational decisions as well as irrationality in pricing behaviors stems from various contributions to our understanding of behavioral dynamics within and across organizations and theories of decision making that explicitly consider rational limits on human cognitive capabilities (e.g., Cyert and March 1963; March 1978; Simon 1955, 1957). Simon (1955) was prescient in advancing the notion that humans are limited by cognitive and calculative abilities to analyze all the information needed to make accurate rational choices. This form of bounded rationality, while appearing to lead to rational decision making, may be rational only in intentions and not always in its outcomes. Instead, individuals in organizations engage in satisficing rather than optimizing (Simon 1957). The limitations imposed by bounded-ness of rationality are particularly severe when decision makers face situations that are uncertain, complex and/or ambiguous (Duncan 1972; Spender 1989; Williamson 1975).

Behavioral decision theories have identified several strategies through which managers reduce the complexity in decision making and/or deal with perceived uncertainty (Cyert and March 1963; March 1978; Nelson and Winter 1982; Simon 1947; Weick 1979). Complexity and uncertainty are often dealt with through simplified mental models that attempt to organize knowledge about the environment (Cyert and March 1963). More importantly, managers attempt to satisfice rather than optimize (March 1978) and/or follow various rules-of-thumb or routines or heuristics (Kahneman, Slovic and Tversky 1982; Nelson and Winter 1982). While such simplifications lead to decisions, the resulting decisions may not be fully optimal. 
Pricing research in industrial markets does acknowledge the role of managerial discretion in the price setting process as well as the decision making errors attributed to managers (Liozu 2013; Liozu et al. 2011). However, there is less attention given to putative behavioral issues, particularly the heuristics that may contribute as aids in reducing decision making complexity but also biases that could contribute to bad decisions (Hammond et al. 2006; Liozu 2012). In the context of pricing, Liozu (2013) elaborates managerial attempts to simplify decisions as those of satisficing, following rules of thumb, defining standard operating procedures and organizational routines, and distributed cognitions.

One way to conceptualize the impact of managerial factors in pricing frameworks is to treat individual and group characteristics as specific exogenous factors that impact the price setting process. Indeed, as noted earlier, comprehensive models of buyer behavior consider individual and buying group factors explicitly in models of organizational buyer behaviors. In terms of pricing research, this would lead to examination of various individual and group factors, including but not limited to, managerial characteristics (e.g., age, education, experience, position in the firm), managerial attitudes and dispositions (e.g., risk taking, conservativeness), and group dynamics (e.g., internal politics, group power).

Another way to include the impact of managerial factors in pricing frameworks is to understand how managerial interpretation of issues as well as their biases and heuristics influence the price setting process. In such a framework, there is explicit recognition of the fact that price setting process is influenced not only by contextual factors but also by managerial judgments, and for better or for worse. For example, the impacts of contextual factors such as present in the environment as well as within the organization on the price setting process could be moderated by managerial factors, as shown in Figure 1. In such a framework, there is explicit 
consideration of individual and group judgments that could contribute to decisions other than those suggested by normative frameworks.

\section{Figure 1 about here}

The effects of environmental context on organizational decisions has been studied not only by researchers within business-to-business marketing but also by those in the broader disciplines of strategic marketing and general management. Specifically, with respect to pricing, Morris and Schurink (1993) identify three specific environmental influences - rate of environmental change, market structure heterogeneity and competitive rivalry - on the pricing behaviors. The rate of environmental change or environmental dynamism refers to the pace and extent of changes in the firm's environment (Morris and Schurink 1993; Miller and Freisen 1983). Higher rates of change may call for aggressive pricing and frequent price changes. Market structure heterogeneity refers to the extent to which markets are characterized by homogeneous versus heterogeneous sources of supply as well as customer requirements (Morris and Schurink 1993; Sheth 1985). These would impact whether the firm's price objectives are uniform across various markets or customized to specific markets. Competitive rivalry is the extent to which one or more competitors are in intense competition with the firm for the same groups of suppliers and/or customers. Here, pricing objectives, method and initial prices may be pegged to the competition rather than flowing from solely internal considerations.

Apart from the environmental context, several aspects of the organizational context, or forces within the organization, also have impacts on the price setting process. For example, Lancioni et al. (2005) demonstrate that different groups and departments within the firm may create hurdles and obstacles in the development and implementation of pricing strategy. Also, bureaucratic structures may increase internal administrative and overhead costs (D'Aveni and 
Ravenscraft 1994), which could be reflected in the higher initial prices and/or lack of price flexibility. The degree of autonomy and control over pricing would affect not only the selection of pricing objectives but also the choice of pricing methods and the flexibility in pricing. On one hand, it appears that CEO influences in price setting actually enhances pricing capabilities, but on the other hand, it may be argued that top management involvement in price setting reduces the decision-making autonomy of functional managers (Lancioni et al. 2005; Liozu and Hinterhuber 2013). Recent research has also shown that a firm's pricing capability is a distinct organizational resource and an important source of competitive advantage (Dutta et al. 2002; Liozu and Hinterhuber 2014).

The above discussion provides a summary view of how some forces in the environmental context and organizational context would affect the price setting process. However, the discussion thus far does not take into account individual managerial issues in decision making. From the current literature on behavioral decision making approaches, we can identify issue interpretation, cognitive biases and heuristics as three major managerial factors that would affect the influence of contextual forces on the prices setting process (see Figure 1). We briefly discuss each of the three factors below.

\section{Issue Interpretation}

Research in organizational behavior, drawing from influences from psychology and sociology, has brought attention to how the context affects individuals and groups (Mowday and Sutton 1993). Specifically, it has been shown it is important to understand how decision makers interpret their contexts (Mowday and Sutton 1993; Thomas and McDaniel 1990). The relevant context can be interpreted as an "opportunity" or a "threat" (Dutton and Jackson 1987; Thomas, 
Clark and Gioia 1993). As Dutton and Jackson (1987; p. 80) elaborate: "the opportunity category implies a positive situation in which a gain is likely and over which one has a fair amount of control; in contrast, the "threat" category implies a negative situation in which a loss is likely and over which one has relatively little control" (emphasis in the original). Thus, the elements needed for categorization of the context as an opportunity or threat are the perception of the situation as positive or negative, the evaluation of the outcome as a gain or loss, and the perception of control.

In terms of the framework offered in Figure 1, both the environmental and organizational context could be subject to interpretation as opportunities or threats. As Thomas et al. (1993) develop from the literature, the specific interpretation of the context matters since it affects not only the mobilization of action in a particular direction but also the levels of risk taking, involvement, and commitment. Thus, interpretation of the environmental context or the framing of the strategic issue would contribute not only to the depth of decision-making but also the decision choices made. In the case of price setting, interpretation of the context as an opportunity may enable the involvement of multiple groups from the organization in the price setting process (Dutton and Jackson 1987); contribute to the development of risk-taking objectives and price taking strategies, and; may lead to prices that attempt to skim the market. On the other hand, interpretation of the context as a threat could lead to more conservative and isolationist approaches to price setting. Therefore, how managers interpret the context must be made a relevant factor in the study of pricing behaviors in business-to-business contexts.

\section{Cognitive Biases}

Recent approaches in the field of behavioral economics and behavioral decision making suggest that far from expecting rational decision-making within organizations, managers are 
"fundamentally irrational" and their decisions are influenced by cognitive biases (Ariely 2009). Simply defined, cognitive biases are subjective opinions or predispositions that may be due to the systematic use of some simple decision rules, heuristics, or "rules of thumb" (Bazerman 1990; Das and Teng 1999; Kahneman, Slovic and Tversky 1982). The resulting decisions often deviate from outcomes that are suggested by the application of a rational calculus (Ariely 2009; Lovallo and Sibony 2010). Thus, in the context of pricing, the consequent impact of individual factors in price setting could lead to deviations from prices suggested by normative frameworks (Urbany 2001).

While the study of behavioral biases within marketing is more prevalent for understanding consumer markets, there is scarce research within marketing of the various psychological and group decision biases that are held by managers, especially pricing decision makers. We extract, primarily from the fields of behavioral economics and behavioral finance, some relevant biases that may affect each stage of the pricing plan comprising of setting objectives, determining demand, determining costs, analyzing competition, selecting a pricing method and setting the price. These are summarized in Table 1.

\section{Table 1 about here}

Apart from the above studies, the relative neglect of studies of behavioral biases in business-to-business markets, especially within pricing, may be due to the assumption that individual factors matter less in a firm's strategic decisions. However, research within finance and strategy literatures suggests that managers in organizations that have systematic processes for collective decision making are also prone to several behavioral biases. 
Table 1 organizes the pricing issues along the lines of the systematic pricing plan suggested by Lancioni (2005b). Several putative behavioral biases that may affect managerial decisions are then identified from literature along with their implications for pricing. A link is attempted between specific biases that may be present at each stage of the pricing decisionmaking along with a descriptive impact of such biases. Two caveats are in order: one, some of the biases listed at each stage could affect other stages as well and two, the organization of the biases and impacts are not based on prior empirical research, which is currently lacking anyway. However, the putative behavioral biases could serve to make a case for understanding whether such biases are manifest in pricing decisions as well as the consequent impacts of these biases.

In the context of pricing decisions, such biases play an important role in interpreting the environmental context and also translating the organizational objectives into pricing behaviors. Managers may underestimate uncertainty and engage in overconfident decisions, or they may be satisfied with merely good enough performance outcomes. Table 1 provides the various possible biases that may impede the translation of organizational priorities, given the environmental context, into prices setting behaviors that could be considered optimal.

\section{Heuristics}

Research in behavioral decision theory has shown that individuals, including managers, use unconscious routines in decision making (Hammond et al. 2006). These heuristics serve to reduce or at least, help manage, the complexities in understanding the decision context as well as reacting to it. These rules are also enshrined in organizational routines and organizational knowledge and process experience enables managers to learn heuristics (Bingham and Eisenhardt 2011). 
Prior literature has shown that managers rely on simple rules and methods of pricing so much that they appear to lack knowledge and understanding (Morris and Morris 1990). Also, simple pricing methods, such as cost-plus pricing, are relied upon more than other more sophisticated approaches to pricing (Ingenbleek 2007). In the context of behavioral decision theory, the application of the cost-plus heuristic is a managerial mechanism of coping with the complexity involved in pricing (Liozu 2012). In a vast majority of cases, it is possible that such a heuristic enables effective price setting; however, in other cases, the application of inappropriate heuristic could result in damaging consequences for the firm's revenues and overall performance. Thus, knowing which heuristic is appropriate given the environmental and organizational context may serve to reduce some of the pricing errors. More importantly, periodic evaluation of the heuristics used and the contexts in which they are used could contribute to better decision making.

Two brief case examples on pricing of solutions and relationship selling illustrate the possible operations of managerial factors noted above in current pricing practices. The primary purpose of these vignettes is to highlight our contention that managerial issues in the price setting process may detract from effective price setting.

\section{Pricing of Solutions}

Over the last several years, major firms such as IBM, HP and others have focused on marketing integrated customer solutions rather than merely products. Essentially, solutions involve an almost seamless integration of products and services that are customized to specific customer needs (Davies, Brady, and Hobday 2006; Sawhney 2006). The high levels of technical and commercial integration of solutions make these more than merely product or price bundles (Krishnamurthy et al. 2003; Sawhney 2006). Customized and well-integrated solutions promise 
to offer great value to customers and greater margins for the firm; however, it has been suggested that only few firms have been successful in their solutions marketing strategies (Johansson et al. 2003; Krishnamurthy et al. 2003). In fact, one study noted that as many as three-fourths of the firms that had tried offering solutions failed to achieve their objectives (Krishnamurthy et al. 2003). It was observed that only 20 to $25 \%$ of the firms realized price premiums from their solution offerings (Roegner and Gobbi 2001). Apart from issues in the design, development and marketing of solutions, one major reason why many solutions marketers failed to recover the high costs of investments is because customers often did not perceive the premium prices charged for solutions as justified compared to their own valuation of the offerings (Johansson et al. 2003; Krishnamurthy et al. 2003; Sharma and Iyer 2011). This was because firms priced their solutions only after they were developed rather than much before and many simply extended their existing pricing methods to solutions (Johansson et al. 2003; Roegner and Gobbi 2001).

Thus, rather than focusing on customer value, target prices and appropriate pricing strategies, firms treated a radically different offering quite the same as far as pricing was concerned. Given the very different context (solutions as compared to individual products or even product bundles), managers may have been quite optimistic in viewing solutions as an opportunity to extract premium prices without considering whether such solutions enhanced customer value. Thus, the interpretation of the context as an opportunity could have led to greater risk taking and possibly less in-depth analysis of the situation and the pricing decision.

It could also be possible that managers may be operating under a status quo bias and did not perceive that integrated solutions were novel offerings that required changes to existing pricing outlooks and price setting processes and/or the use of new methods to price integrated solutions (see for example, Samuelson and Zeckhauser 1988). Or, managers may be subject to a 
familiarity bias and prefer existing heuristics, such as cost-plus pricing, that they are more familiar with (see for example, Huberman 2001), rather than use new methods to understand and extract customer perceived value of integrated solutions. Thus, behavioral approaches enable us to go beyond simply the decision and its consequences and help identify possible causes for suboptimal prices and eventually, help minimize their impacts.

\section{Relationship Pricing}

While relationship marketing approaches have been in vogue in various industries since the 1980s and in academic literature on business-to-business marketing soon after, few firms have been successful in developing and implementing profitable customer relationship marketing strategies (Richards and Jones 2008). The profitability of a relationship marketing approach hinges on the assumption that loyal customers would pay premium prices. However, this is not always true and firms often do not take into account the different costs of serving different types of customers when determining the price (Reinartz and Kumar 2000). While techniques are available that would help firms better segment their customer base and price accordingly (Rust et al. 2001), there is scant evidence to suggest that pricing in relationship settings is taken as seriously as it should be. In fact, evidence from commercial banking suggests that many commercial banks do not invest in creating relationships with their customers and their pricing remains "poorly informed and inconsistent" (Helps and Saari 2005). Thus, rather than focusing on the long-term relationship, firms often take a much narrow view of the market and engage in pricing over the transaction rather than through the relationship (Nunes and Hanson 2012).

From the behavioral perspective, such a short-term focus on relationships may be the result of a loss aversion bias (see for example, Tversky and Kahneman 1991). Managers may be 
operating under the assumption that costly investments upfront in building relationships may often lead to losses over the long-term, especially when the firm and customers engage in easily terminable contractual relationships or non-contractual relationships. Thus, a behavioral perspective may help us understand the reasons why managers view short-term profits (including profits from transactional customers) as more important compared to longer-term recovery of investments from relationships (Reinartz and Kumar 2000).

\section{Implications and Extensions to Theory and Research}

Descriptive realities of the individual influences on price setting within organizations can be explained by two alternative perspectives. One, the popular research stream pioneered by Tversky, Kahneman and others maintains that individuals are subject to biases and these biases contribute to deviations from behaviors and outcomes that are suggested by normative models of economic decision making (Tversky and Kahneman 1974; Kahneman, Slovic and Tversky 1982). Thus, this perspective holds that while models of economic rationality may suggest specific optimal decisions and outcomes, actual decisions are often suboptimal and error-prone due to biases in human inference (Gigerenzer and Goldstein 1996).

The second perspective that has often developed under the shadow of the biases program noted above maintains that economic rationality is a myth and optimality is a chimerical objective. This perspective is more directly influenced by Herbert Simon's (1955) views of bounded rationality and maintains that the goals of individuals and systems are those of satisficing rather than optimizing (Gigerenzer and Goldstein 1996). Thus, the appropriate goal is to seek out the option, alternative or object that meets the organism's aspirational level rather than engage in a complex and unachievable search for optimality that is doomed at the outset, 
given limits on human cognition and computational abilities (Gigerenzer and Goldstein 1996; Simon 1955).

While we are not in a position to engage in or even add to the debate between the two perspectives (see, for example, Kahneman and Tversky 1996; Gigerenzer 1996), suffice it to say that both perspectives point to limits in individual decision-making that may lead to suboptimal decisions. In the case of prices, whether approached from the perspectives of biases or from the objectives of satisficing, suboptimal prices are a reality and could detract from supraorganizational objectives, including long-term profits.

Behavioral research on pricing is now the dominant framework for analyzing pricing within consumer marketing. For over the last four decades, consumer perceptions of price and their reactions to prices and price changes have been the subject of much academic research on pricing. However, similar behavioral theories and frameworks are largely absent within business-to-business research. Part of the reason could be the conceptualization of business-tobusiness pricing as a rational organizational decision that is impervious to individual tastes and preferences. Therefore, it is possible that academic researchers view business-to-business pricing decisions as rational, with any pricing errors attributed not to psychological factors but to lapses in strategy.

The application of behavioral thinking to price setting by firms has the potential to enhance our understanding in several different ways. First, by challenging the assumption that prices are rationally set, it opens the door to pricing that works rather than prices that are optimal. This may bring theory and practice closer to appropriate pricing in different contexts rather than relying on general assumptions of rationality and optimality. Second, opening the door to considering behavioral biases as a contributor to suboptimal pricing leads to an 
examination of putative causes rather than offering normative frameworks that may be inappropriately applied in practice. Thus, there may be an explicit re-examination of current theory rather than merely critiquing practice for failure to follow theory. Third, the study of behavioral biases helps understand reality as it is rather than whether a theory applies to reality. This key focus on ontology enables descriptive theories that would complement deductive logic to help us better grasp realities.

Using insights from other disciplines, primarily behavioral economics, a behavioral approach to strategy brings the field of strategy closer to reality by taking into explicit account "realistic assumptions about human cognition, emotion, and social interaction" (Powell et al. 2011; p. 1369). Behavioral approaches do not reject rationality; instead, they reject the rationality in humans as an unchallenged assumption and optimality as the desired and achievable objective. Cognizant of the bounded-ness of human rationality as well as the variety of biases in decision making, behavioral approaches view rationality as a process, not as something that is given or as an outcome (Simon 1955; Levinthal 2011; March 1994). In the behavioral world, only presumed rational choices are made, satisficing is more relevant than optimizing, and analysis and actions reveal the boundary conditions of decision making and choices (Simon 1955; Levinthal 2011; March 1994).

Within business-to-business marketing, the focus on normative models of increasing sophistication tends to move us away from a more accurate picture of the real world. While deductive logic may be a useful starting place, descriptive and empirical realities tell us how it is really out there. Such revisions to our conceptions of reality would help us develop theories not only for a better understanding of the business-to-business world, but also for providing practical 
guidelines for managerial action. We offer some approaches to research and theory in the section below.

\section{Implications for Theory Building}

While behavioral issues and biases have been a focus of inquiry within marketing for some time now, there has been less emphasis on the exploration of these themes within the area of business-to-business marketing in general, and managerial pricing strategies, in particular. We have made only a preliminary and exploratory contribution to the study of behavioral biases in price setting, including the types of biases that may detract from optimum prices in businessto-business marketing. As noted by Powell et al. (2011), the key concern in behavioral strategy is not good research but "a lack of conceptual unity" (p. 1371). While some prior research has pointed to suboptimal pricing behaviors (notably, Kopalle, Mela and Marsh 1999; Little and Shapiro 1980, and; Urbany 2001), we have explored the idea that behavioral biases could result in suboptimal managerial price setting behaviors. In other words, we have introduced the possibility that suboptimal price setting by managers may be due to various inherent biases and predispositions held by them. Behavioral approaches to understanding suboptimal pricing goes beyond merely identifying the incidence or prevalence of suboptimal pricing; instead, by explicitly considering the possibility that managerial decisions may be biased, the door is opened for an examination of what was wrong with decisions and how decision making may be improved. By questioning managerial assumptions and engaging in behavioral experimentation, as suggested by Ariely (2009), firms can begin to understand irrationality and engage in decisions that could confront biases and reduce their impacts (Lovallo and Sibony 2010). 
The framework we have offered sheds some light on the various sources of behavioral biases that could impact price setting. However, as all frameworks go, there is a need to ground conceptual insights into empirical realities. This is especially true in the context of behavioral issues and cognitive psychology, wherein Gigerenzer (1991) notes that scientific tools could contribute to the development of new theoretical concepts and metaphors.

The recognition that human cognition and processing capabilities are limited and that human decision-making is subject to various biases is the first step in a behavioral approach to understanding pricing in business-to-business markets. While normative approaches may offer appropriate tools and techniques, the key issue may not be whether they work, but why they are not used more often. Moreover, the decision-making context may be more complex as compared to the simplistic assumptions in extant models of pricing. More importantly, the study of deviations from rationality offer a better perspective on the world we live in rather than the optimal worlds we should strive to live in. Therefore, understanding behavioral biases and confronting them head-on may be the best way to minimize the incidence of suboptimal pricing. However, since this research stream is still in its infancy, future research focus could be on identifying the various behavioral biases and unravelling their impacts, as noted below.

\section{An Agenda for Future Research}

Some research on organizational buying, however, has been quite prescient in its acknowledgment of various behavioral and individual factors that affect otherwise "rational" buying decisions (Montgomery1975; Wilson 1984; Woodside and Wilson 2000). For example, Montgomery (1975) found that a vast majority of new items accepted by supermarket buyers were dropped within 12 months, suggesting a rather high frequency of mistakes in buying 
decisions. An analysis of buying decisions in the utility industry by Wilson (1984) revealed that prices were revised only annually unless adjustments were requested by vendors. Woodside and Wilson (2000) found that in marketer-buyer relationships in business-to-business contexts, both parties framed "problems and people using a limited number of issues and categories" (p.365). This suggests that instead of exploring all possible alternatives, contingencies and outcomes as suggested by rational economic models, managers relied more on implicit and limited decision framing processes.

Given the lack of research on behavioral issues in business-to-business pricing, leave alone the research on biases in such pricing, much work needs to be done to obtain a state-of-theart knowledge of extant realities. Within the area of pricing research, Urbany (2001) was prescient in his call for research that would enable greater understanding of errors in pricing, their contributory causes, and consequent impacts. In an attempt to understand how cognitive biases may affect price setting, we have only made a beginning in identifying possible biases that could impact price setting processes in the business-to-business marketing contexts. We hope that this beginning may be an appropriate start for attempts to answer other relevant questions empirically to further our knowledge on the specific types of cognitive biases and how they impact the pricing decision in organizations. Some these directions for future research are briefly elaborated below.

1. What manifest forms of behavioral biases impact pricing decisions? Currently, except for a few frameworks, we do not have adequate knowledge of what types of biases may be present in business-to-business marketing pricing decisions as well as how these may contribute to suboptimal pricing and other systematic errors. We need more cross-industry research to identify the phenomena and understand the potential manifestations of various 
behavioral biases. Moreover, it may be possible that different forms of behavioral biases may be manifest in different industries or in the same industry across different country contexts. An important research question may be: What are the most relevant biases operational in pricing decisions within specific organizations, industries, or cultural contexts?

2. How and to what extent do behavioral biases impact pricing decisions? While some forms of biases may not be much cause for concern, severe deviations from rationality and optimality need to be understood. We need empirical research on the extent to which various behavioral biases may contribute to suboptimal decisions. Here as well, the impacts of biases in some industries may be more severe than others. For example, given the high costs of drug development, the impacts of biases may be more severe in the pharmaceutical industry as compared to other industries. Research specific to industries may be needed, even if such industry research is considered by some as less academic. An important research question may be: What are the consequent impacts of various biases, given the premise that irrationality is simply human nature and that some forms of biases may have a more deleterious impact than others that are merely benign?

3. How do managers rationalize their pricing decisions? Given the possibility of behavioral biases, do managers recognize their own failures? If not, how do managers rationalize their pricing decisions, especially given the fact that pricing decisions in business-to-business contexts may need organizational approval and review? Research is needed not only on managerial cognitive frameworks but also on their explanations for the various pricing decisions taken. Such research may also uncover broader group and organizational influences on suboptimal pricing, beyond the control of individual managers. Thus, while 
biases may be hidden from view, the decision and its consequent impacts can be observed. For example, Lovallo and Sibony (2010) suggest that confident managers are more likely to have their plans approved as compared to those who identify all the various risks and eventualities inherent in the decision. When confidently proposed plans fail, managerial assumptions need to be re-examined. Thus, apart from identifying managerial biases as contributing to specific decisions, an important research question may be: How are bad decisions rationalized?

4. How do behavioral biases in pricing play out in different cultures? While research on international pricing has focused on offering normative models for use by export and other international managers, we know less about the price setting process in different cultural contexts. For example, is price setting in traditional cultures the sole prerogative of the senior executive? An important research question may be: Does price setting in different cultures impacted by various other behavioral biases? We need research on identifying the cultural incidence of various biases and their impacts to fully understand the cultural context of pricing.

5. What strategies should be adopted to minimize biases and their impacts? While much of the research on behavioral strategy has been descriptive while business-to-business pricing is more normative, we need to understand what managers and organizations could do to minimize the various potential behavioral biases and their impacts. An important research question may be: What is the effectiveness of various techniques for reducing biases including intra-company coordination, reliance on internal experts, use of outside experts and consultants, and pre-implementation review, among others? 


\section{What is the nature of exchange when both managers and their customers are subject to}

behavioral biases? While extant research on behavioral biases is one-sided, that is, focused on understanding either only individuals, groups or consumers, business-to-business marketing is dyadic. If current research on behavioral issues and biases in pricing from consumer markets could be extended to business customers, then such customers would be prone to biases in their purchasing decisions. However, if managers are also subject to biases, the very nature of the exchange relationship may be drastically different. An important research question may be: How do two biased parties to an exchange view, set and accept prices? Such a research stream could also gain from the vast amount of research done in the area of business negotiations.

\section{Methodological Approaches for Future Research}

There are several inductive approaches already known to marketing and industrial marketing scholars that have the potential to bridge the gap between the behavioral biases we have explored and empirical realities in price setting. In a seminal contribution, Howard and Morgenroth (1968) use a novel approach to study executive decision making, especially with respect to price setting. Given the problems in studying executive decision rules either before or after the fact, they used multiple approaches to gain an in-depth and more accurate understanding of how executives actually take decisions and if such decisions deviated from the optimum. A complex multi-source multi-method research design was used, including interviews, observation of the processes, records of past decisions and various supporting data along with further reviews with responding executives (Howard and Morgenroth 1968). Thus, better insights into actual decision-making can be obtained. 
Similarly, research in the field of organizational buying has used methods such as the analysis of verbal protocols in understanding the processes and realities of decision making (Crow, Olshavsky and Summers 1980; Woodside and Wilson 2000). Woodside and Wilson (2000) find it most appropriate to use verbal protocols or the "think aloud method" (van Someren, Barnard and Sandberg 1994) to understand contingency models relied upon by executives in decision making. Using a novel research method that combines the use of thick descriptions - an approach pioneered in anthropology, most notably by Geertz (1973) - along with creative uses of think aloud method and interviews, Woodside and Wilson (2000) demonstrate that even complex aspects of decision making can be mapped by tapping into the thoughts and behaviors of decision makers in real-life situations.

Other more direct approaches to counter biases include behavioral experimentation, as suggested by Ariely (2009) and leadership commitment and cultural change, as suggested by Lovallo and Sibony (2010). Ariely (2009) contends that firms and managers must question their assumptions and engage qualified experts who would help the firm in behavioral experimentation and small trials. Similarly, Lovallo and Sibony (2010) suggest that biases should be recognized and discussed within the organization and confronted directly with debiasing practices and tools.

What we have offered here are the first steps - the contention that suboptimal pricing may be the result of various behavioral biases and an identification of the relevant biases affecting price setting. However, understanding decision making in its actual context offers the best potential for uncovering the implicit decision rules and the biases in decision making. 


\section{Challenges of Behavioral Research}

Answers to the above research questions would greatly enhance our understanding of the complexities involved when behavioral biases affect pricing decisions. However, such research may not be easy to undertake. For one, the types of controlled experiments that are in use in the areas of behavioral economics and marketing may not be possible among busy executives in business-to-business contexts. Secondly, given organizational and career pressures, managers may be less forthcoming about their choices, especially through methods such as personal interviews. Third, empirical research on uncovering group level biases may be hard to undertake.

However, given the increase in executive education programs in business schools, several practicing managers are now enrolled as students in such programs. These manager-students not only provide a somewhat homogeneous sample but may also be more willing to participate in academic research. With suitable sample selection criteria, methods that are used in other disciplines to study behavioral biases can also be applied to understand biases in business-tobusiness pricing. Thus, despite challenges, the field is rife with opportunities for future research.

\section{Implications for Managers}

The idea that managerial decisions may be subject to various biases that yield suboptimal outcomes may be quite distressing for managers keen on taking the best decisions and obtaining the best results. Also, given bounded rationality and satisficing, optimality may be an illusory objective. However, despite such pessimism, recent research actually suggests that a variety of approaches and heuristics actually followed by decision makers results in decisions that either overcome some of the limitations of the various biases or contribute to decisions that are 
sometimes even better than those suggested by models of optimality. For example, we can use research by the medical profession that seeks to reduce biases in decision-making by doctors as a starting point.

Examining a variety of research conducted in the context of business, health care and legal organizations and institutions, Gigerenzer and Gaissmaier (2011) conclude that heuristic decisions, rather than always contributing to errors, are sometimes quite valuable and more accurate in decision making. Heuristics are prompted by effort reduction considerations and enable making decisions rapidly with minimal information, and sometimes more accurately, as compared to complex models (Gigerenzer and Gaissmaier 2011). Thus, simple and/or intuitive heuristics that are adaptive often reduce errors in decision making.

In the last column of Table 1, we offer various insights from prior research on how the biases noted at each stage of price setting may be reduced. An important insight is the role of adaptive learning - that is feedback that is obtained from prior decisions - in reducing biases and errors in the future (Al-Najjar, Baliga and Besanko 2008; Senge 1994). Thus, it is possible that experts are those individuals in organizations who learn through experience and thus, refine their decision making abilities to the extent that the outcomes of their decision making rivals complex models. Given limits on attention and memory, experts reason analytically and intuitively and gain constantly from experience (Prietula and Simon 1989).

\section{Conclusion}

Suboptimal pricing by decision-makers could be attributed to a variety of factors. For one, pricing involves inputs from multiple divisions within the firm, such as finance and accounting, among others, and stakeholders within and outside the firm, including 
intermediaries. Moreover, pricing involves considerations of a variety of complex factors within the firm, including appropriate costing and cost allocations, marginal profits, etc., as well as outside the firm, including customer demand and competition. The complexity of the pricing process itself may contribute to suboptimal price setting in business-to-business markets.

Second, accuracy in pricing may call for information beyond what is available or can be obtained by the decision-maker. Normative models of pricing may require detailed information of demand and supply as well as future projections of costs and demand. The absence of complete and accurate information may also contribute to prices that are recognized as suboptimal only at a future date and after detailed examination.

Third, pricing is a decision that needs to be continuously examined and frequently adjusted. This calls for detailed information on the environment as well as information on the impacts of prices on the firm's marginal profits. The inability to respond to such internal and external considerations fairly quickly may also contribute to pricing errors that affect the organization's objectives and performance adversely.

While impacts of various pricing errors emerging due to organizational factors could be minimized by appropriate organizational structures and emphasis on information gathering and information use, we have focused on the behavioral issues that may be more difficult to address. The study of business-to-business pricing is ready for a change from its extant focus on normative models and frameworks to descriptive research on how managers actually set prices. In this context, the various behavioral biases identified in other disciplines could provide explanations for suboptimal pricing as well as deviations from rational price-setting. In this paper, we have merely scratched the surface of a rich, growing and rewarding field of inquiry and are hopeful that future research would greatly enhance our understanding of pricing practices 
in business-to-business marketing. Such an understanding would serve to greatly reduce the wide chasm between academic theory and managerial practice. 


\section{References}

Accenture (2011). Going for Growth, available at http://www.accenture.com/SiteCollectionDocuments/PDF/Accenture-Going-for-Growth.pdf. [Accessed July 26, 2013].

Al-Najjar, N., Baliga, S., \& Besank, D. (2008). Market forces meet behavioral biases: cost misallocation and irrational pricing. RAND Journal of Economics, 39(1), 214-237.

Anderson, J.C., Thomson, J.B.L. \& Wynstra, F. (2000). Combining value and price to make purchase decisions in business markets. International Journal of Research in Marketing, 17, 307-329.

Andersson, Ola and Holm, Håkan J. and Tyran, Jean-Robert and Wengström, Erik (2013). Deciding for Others Reduces Loss Aversion (September 17, 2013). Available at SSRN: $\underline{\text { http://ssrn.com/abstract }=2328642}$

Ariely, D. (2009). The end of rational economics. Harvard Business Review, July-August, 7884.

Arkes, H. \& Blumer, C. (1985). The psychology of sunk cost. Organizational Behavior and Human Decision Process, 35, 124-140.

Baker, W.L., Marn, M.V. \& Zawada, C.C. (2010a). Building a better pricing infrastructure. McKinsey Quarterly, August, 1-6.

Baker, W.L., Marn, M.V. \& Zawada, C.C. (2010b). Do you have a long-term pricing strategy? McKinsey Quarterly, October, 1-7.

Barber, B. \& Odean, T. (1999). The courage of misguided convictions. Financial Analysts Journal, 55, 41-55.

Barclay, D.W., \& Bunn, M.D. (2006). Process heuristics in organizational buying: starting to fill a gap. Journal of Business Research, 59, 186-194.

Bazerman, M.H. (1990). Judgment in managerial decision-making, $2^{\text {nd }}$ ed. New York: John Wiley and Sons.

Beggan, J.K. (1992). On the social nature of nonsocial perception: the mere ownership effect. Journal of Personality and Social Psychology, 62, 229-237.

Bellizzi, J.A. (1979). Product type and the relative influence of buyers in commercial construction. Industrial Marketing Management, 8, 213-220.

Bingham, C.B., \& Eisenhardt, K.M. (2011). Rational heuristics: the 'simple rules' that strategists learn from process experience. Strategic Management Journal, 32, 1437-1464. 
Brown, B.P., Zablah, A.R., Bellenger, D.N., \& Johnston, W.J. (2011). When do b2b brands influence the decision making of organizational buyers? an examination of the relationship between purchase risk and brand sensitivity. International Journal of Research in Marketing, 28, 194-204.

Brown, B.P., Zablah, A.R., Bellenger, D.N. \& Donthu, N. (2012). What factors influence buying center brand sensitivity? Industrial Marketing Management, 41, 508-520.

Carricano, M. (2014). Pricing myopia: do leading companies capture the full value of their pricing strategies? Management Decision, 52, 159-178.

Coval, J. D., \& Shumway, T. (2005). Do behavioral biases affect prices? Journal of Finance, 60, $1-34$.

Crow, L.E. \& Lindquist, J.D. (1982). Buyers differ in evaluating suppliers. Industrial Marketing Management, 11, 205-214.

Crow, L. E., Olshavsky, R. W., \& Summers, J. O. (1980). Industrial buyers' choice strategies: a protocol analysis. Journal of Marketing Research, 17, 34-44.

Cudahy, G., \& Coleman, G.L. (2007). The price is right . . isn’t it? Outlook, 1, 1-8.

Cyert, R.M. \& March, J.G. (1963). A behavioral theory of the firm. Englewood Cliffs, NJ: Prentice Hall.

Daniel, K., \& Titman, S. (1999). Market efficiency in an irrational world. Financial Analysts' Journal, 55, 28-40.

Das, T.K., \& Teng, B-S. (1999). Cognitive biases and strategic decision processes. Journal of Management Studies, 36, 757-778.

D’Aveni, R.A., \& Ravenscraft, D.J. (1994). Economics of integration versus bureaucracy costs: does vertical integration improve performance? Academy of Management Journal, 37, 11671206.

Davies, A., Brady, T., \& Hobday, M. (2006). Charting a path toward integrated solutions. MIT Sloan Management Review, 47, 39-48.

De Bondt, W. F. M., \& Thaler, R. H. (1995). Financial decision-making in markets and firms: a behavioral perspective. In R. A. Jarrow, V. Maksimovic \& W. T. Ziemba (Eds.), Handbooks in Operations Research and Management Science, (Vol. 9, pp. 385-410). Amsterdam: North Holland.

Duncan, R. (1972). Characteristics of organizational environments and perceived environmental uncertainty. Administrative Science Quarterly, 17, 313-327. 
Dutta, S., Bergen, M. Levy, D., Ritson, M., \& Zbaracki, M. (2002). Pricing as a strategic capability. MIT Sloan Management Review, 61-66.

Dutton, J.E., \& Jackson, S.E. (1987). Categorizing strategic issues: links to organizational action. Academy of Management Review, 12, 76-90.

Eugster, C.C., Kakkar, J.N., \& Roegner, E.V. (2000). Bringing discipline to pricing. McKinsey Quarterly, 1, 132-130.

Forman, H. \& Hunt, J.M. (2005). Managing the influence of internal and external determinants on international industrial pricing strategies. Industrial Marketing Management, 34, 133-146.

Forman, H., \& Hunt, J.M. (2013). The effect of decision context on perceived risk in pricing strategies: how managers view uncontrollable forces. Journal of Product and Brand Management, 22, 79-86.

Fox, C.R., \& Levav, J. (2000). Familiarity bias and belief reversal in relative likelihood judgment. Organizational Behavior and Human Decision Processes, 82, 268-292.

Frenzen, H., Hansen, A.-K., Krafft, M., Mantrala, M.K. \& Schmidt, S. (2011). Delegation of pricing authority to the sales force: an agency-theoretic perspective of its determinants and impact on performance. International Journal of Research in Marketing, 27, 58-68.

Geertz, C. (1973). The interpretation of cultures. New York: Basic Books.

George, J.F., Duffy, K., \& Ahuja, M. (2000). Countering the anchoring and adjustment bias with decision support systems. Decision Support Systems, 29, 195-206.

Gigerenzer, G. (1991). From tools to theories: a heuristic of discovery in cognitive psychology. Psychological Review, 98, 254-267.

Gigerenzer, G. (1996). On Narrow norms and vague heuristics: A reply to Kahneman and Tversky (1996). Psychological Review, 103 (3), 582-591.

Gigerenzer, G., \& Gaissmaier, G. (2011). Heuristic decision making. Annual Review of Psychology, 62, 451-482.

Gigerenzer, G., \& Goldstein, D. G. (1996). Reasoning the fast and frugal way: Models of bounded rationality. Psychological Review, 103, 650-669.

Griffith, D.E. \& Rust, R.T. (1997). The price of competitiveness in competitive pricing. Journal of the Academy of Marketing Science, 25, 109-116.

Guiltinan, J. (1976). Risk-aversive pricing policies: problems and alternatives. Journal of Marketing, 40, 10-15. 
Hafenbrack, A.C., Kinias, Z., \& Barsade, S. (2013). Debiasing the mind through meditation: mindfulness and the sunk-cost bias. Psychological Science, published online December 6, 2013, DOI: $10.1177 / 0956797613503853$.

Hall, R.I. \& Hitch, C.J. (1939). Price theory and business behavior. Oxford Economic Papers, 2, $12-45$.

Hammond, J.S., Keeney, R., \& Raiffa, H. (2006). The hidden traps in decision making. Harvard Business Review, 76, 47-58.

Hawes, J.M. \& Barnhouse, S.H. (1987). How purchasing agents handle personal risk. Industrial Marketing Management, 16, 287-293.

Helps, B., \& Saari, K. (2005). Relationship pricing for profitability. Commercial Lending Review, 20, 3-6.

Hinterhuber, A. (2004). Towards value-based pricing - an integrative framework for decision making. Industrial Marketing Management, 33, 765-778.

Hogan, J., \& Lucke, T. (2006). Driving growth with new products: common pricing traps to avoid. Journal of Business Strategy, 27, 54-58.

Howard, J.A., \& Morgenroth, W.M. (1968), Information processing model of executive decision. Management Science, 14, 416-428.

Huberman, G. (2001). Familiarity breeds investment. Review of Financial Studies, 14, 659-680.

Hunt, J.M., \& Forman, H. (2006). The role of perceived risk in pricing strategy for industrial products: a point-of-view perspective. Journal of Product and Brand Management, 15, 386-393.

Ingenbleek, P. (2007). Value-informed pricing in its organizational context: literature review, conceptual framework, and directions for future research. Journal of Product and Brand Management, 16 (7), 441-458.

Johansson, J.E., Krishnamurthy, C., \& Schlissberg, H.E. (2003). Solving the solutions problem. McKinsey Quarterly, 3, 116-125.

Johnston, W.J. \& Lewin, J.E. (1996). Organizational buying behavior: toward an integrative framework. Journal of Business Research, 35, 1-15.

Kahneman, D., Slovic, P., \& Tversky, A., (Eds.). (1982). Judgment under uncertainty: Heuristics and biases. Cambridge, UK: Cambridge University Press.

Kahneman, D. \& Tversky, A. (1979). Prospect theory: An analysis of decision under risk, Econometrica, 47, 263-291. 
Kahneman, D., \& Tversky, A. (1996). On the reality of cognitive illusions. Psychological Review, 103, 582-591.

Kauffman, R.G. (1996). Influences on organizational buying choice processes: future research directions. Journal of Business and Industrial Marketing, 11, 94-107.

Kohli, A. (1989). Determinants of influence in organizational buying: a contingency approach. Journal of Marketing, 53, 50-65.

Kopalle, P., Mela, C.F., \& Marsh, L. (1999). The dynamic effect of discounting on sales: empirical analysis and normative pricing implications. Marketing Science, 18, 317-333.

Krishnamurthy, C., Johansson, J., \& Schlissberg, H. (2003). Solutions selling: is the pain worth the gain? McKinsey Marketing Solutions, April, http://www.mckinsey.com/practices/marketing/ourknowledge/pdf/Solutions_SolutionsSelling.pd $\underline{\mathrm{f}}$

Lancioni, R. (2005a). Pricing issues in industrial marketing. Industrial Marketing Management, $34,111-114$.

Lancioni, R. (2005b). A strategic approach to industrial product pricing: the pricing plan. Industrial Marketing Management, 34, 177-183.

Lancioni, R., Schau, H.J., \& Smith, M.F. (2005). Intraorganizational influences on business-tobusiness pricing strategies: a political economy perspective. Industrial Marketing Management, 34, 123-131.

Levinthal, D.A. (2011). A behavioral approach to strategy - what's the alternative? Strategic Management Journal, 32, 1517-1523.

Liozu, S.M. (2012). Complexity theory and pricing management. Journal of Professional Pricing, Q3, 10-17.

Liozu, S.M. (2013). Irrational pricing decisions in organizations. Journal of Professional Pricing, Q2, 13-19.

Liozu, S.M., Boland, R.J. Jr., Hinterhuber, A., \& Perelli, S. (2011). Industrial pricing orientation: the organizational transformation to value-based pricing. Paper presented at the First International Conference on Engaged Management Scholarship, Case Western Reserve University, Cleveland, Ohio, June, [Available at: http://ssrn.com/abstract=1839838].

Liozu, S.M., \& Hinterhuber, A. (2013). CEO championing of pricing, pricing capabilities and firm performance in industrial firms. Industrial Marketing Management, 42, 633-643.

Liozu, S.M., \& Hinterhuber, A. (2014). Pricing capabilities: the design, development, and validation of a scale. Management Decision, 52, 144-158. 
Little, J.D.C., \& Shapiro, J.F. (1980). A theory of pricing nonfeatured products in supermarkets. Journal of Business, 53, s199-s209.

Lovallo, D., \& Sibony, O. (2010). The case for behavioral strategy. McKinsey Quarterly, March, $1-14$.

March, J.G. (1978). Bounded rationality, ambiguity, and the engineering of choice. Bell Journal of Economics, 9, 587-608.

March, J.G. (1994). A primer on decision making. New York: Free Press.

Miller, D. \& Friesen, P. (1982). Innovation in conservative and entrepreneurial firms: two models of strategic momentum. Strategic Management Journal, 4, 221-235.

Montgomery, D. B. (1975). New product distribution: an analysis of supermarket buyer decisions. Journal of Marketing Research, 12, 255-264.

Monroe, K.B., \& Cox, J.L. (2001). Pricing practices that endanger profits. Marketing Management, 10, 42-46.

Morris, M.H., \& Calantone, R. (1990). Four components of effective pricing. Industrial Marketing Management, 19, 321-329.

Morris, M.H., \& Morris, G. (1990). Market-oriented pricing: strategies for management. Westport, CT: Quorum Books.

Morris, M.H., \& Schurink, C.v.E. (1993). Pricing behavior in industrial markets. Journal of Business and Industrial Marketing, 8, 28-43.

Mowday, R.T., \& Sutton, R.I. (1993). Organizational behavior: linking individuals and groups to organizational contexts. Annual Review of Psychology, 44, 195-229.

Nagle, T.T., Hogan, J., \& Zale, J. (2010). The strategy and tactics of pricing: a guide to growing more profitably. $\left(5^{\text {th }}\right.$ ed.). Englewood Cliffs, NJ: Prentice Hall.

Nelson, R.R., \& Winter, S.G. (1982). An evolutionary theory of economic change. Cambridge, MA: Belknap Press.

Noble, P.M., \& Gruca, T.S. (1999). Industrial pricing: theory and practice. Marketing Science, $18,435-454$.

Nunes, P.F., \& Hanson, J.G. (2012). Are you taking full advantage of the pricing window? Outlook, 2, http:/www.accenture.com/us-en/outlook/Pages/outlook-journal-2012-taking-fulladvantage-of-pricing-window.aspx 
Oxenfeldt, A.R. (1973). A decision-making structure for price decisions. Journal of Marketing, $37,48-53$.

Ozer, O., \& Zheng, Y. C. (2012). Behavioural issues in pricing management. In O. Ozer \& R. Phillips (Eds.), The Oxford Handbook of Pricing Management (pp. 415-460). Oxford, UK: Oxford University Press.

Powell, T.C., Lovallo, D., \& Fox, C.R. (2011). Behavioral strategy. Strategic Management Journal, 32, 1369-1386.

Prietula, M.J., \& Simon, H.A. (1989). Experts in your midst. Harvard Business Review, 67, 120124.

Puto, C.P., Patton, W.E., III, \& King, R.H. (1985). Risk handling strategies in industrial vendor selection decisions. Journal of Marketing, 49, 89-98.

Qualls, W.J. \& Puto, C.P. (1989). Organizational climate and decision framing: an integrated approach to analyzing industrial buying decisions. Journal of Marketing Research, 26, 179-192.

Reinartz, W.J., \& Kumar, V. (2000). On the profitability of long-life customers in a noncontractual setting: an empirical investigation and implications for marketing. Journal of Marketing, 64, 17-35.

Richards, K.A., \& Jones, E. (2008). Customer relationship management: finding value drivers. Industrial Marketing Management, 37, 120-130.

Robinson, P.J., Faris, C.W. \& Wind, Y. (1967). Industrial buying behavior and creative marketing. Boston, MA: Allyn \& Bacon.

Roegner, E., \& Gobbi, J. (2001). Effective solutions pricing: How to get the best premium from strategic collaborations. McKinsey Marketing Solutions, May, http://www.mckinsey.com/practices/marketing/ourknowledge/pdf/Solutions_SolutionsPricing.pd $\underline{\mathrm{f}}$

Rust, R. T., Lemon, K. N., \& Zeithaml, V. A. (2001). Where should the next marketing dollar go? Marketing Management, 10, 25-28.

Samuelson, W., \& Zeckhauser, R. (1988). Status quo bias in decision making. Journal of Risk and Uncertainty, 1, 7-59.

Sawhney, M. (2006). Going beyond the product: defining, designing and delivering customer solutions. In R.F. Lusch and S.L. Vargo (Eds.), The Service Dominant Logic of Marketing: Dialog, Debate, and Directions (pp. 365-380). Armonk, NY: M.E. Sharpe, Inc.

Senge, Peter (1994). The Fifth Discipline: The Art and Practice of the Learning Organization. New York, NY: Doubleday Publishing. 
Sharma, A., \& Iyer, G.R. (2011). Are pricing policies an impediment to the success of customer solutions? Industrial Marketing Management, 40, 723-29.

Sheth, J.A. (1973). A model of industrial buyer behavior. Journal of Marketing, 37, 50-56.

Sheth, J.A. (1985). New determinants of competitive structures in industrial markets. In R. E. Spekman and D. T. Wilson (Eds.), A Strategic Approach to Business Marketing (pp. 1-18), Chicago: American Marketing Association.

Simon, H.A. (1947). Administrative behavior. New York: The Macmillan Company.

Simon, H.A. (1955). A behavioral model of rational choice. Quarterly Journal of Economics, 69, 99-118.

Simon, H.A. (1957). Models of man. New York: Wiley.

Skouras, T., Avlonitis, G.J., \& Indounas, K.A. (2005). Economics and marketing on pricing: how and why do they differ? Journal of Product and Brand Management, 14, 362-374.

Smith, G.E. (1995). Managerial pricing orientation: the process of making pricing decisions, Pricing Strategy and Practice, 3, 28-39.

Spender, J.-C. (1989). Industry recipes: the nature and sources of managerial judgment. Oxford, UK: Basil Blackwell.

Tellis, G.J. (1986). Beyond the many faces of price: an integration of pricing strategies. Journal of Marketing, 50, 146-160.

Tellis, G.J., \& Johnson, J. (2007). The value of quality. Marketing Science, 26, 758-773.

Thaler, R. (1980). Toward a positive theory of consumer choice. Journal of Economic Behavior and Organization, 1, 39-60.

Thomas, J.B., \& McDaniel, R.R., Jr. (1990). Interpreting strategic issues: effects of strategy and the information-processing structure of top management teams. Academy of Management Journal, 33, 286-306.

Thomas, J.B., Clark, S.M., \& Gioia, D.A. (1993). Strategic sensemaking and organizational performance: linkages among scanning, interpretation, action, and outcomes. Academy of Management Journal, 36, 239-270.

Tversky, A., \& Kahneman, D. (1974). Judgment under uncertainty: heuristics and biases. Science, 185, 1124-1130. 
Tversky, A., \& Kahneman, D. (1991). Loss aversion in riskless choice: a reference dependent model. Quarterly Journal of Economics, (November), 1039-1061

Urbany, J. E. (2001). Justifying profitable pricing. Journal of Product \& Brand Management, 10, 141-159.

van Dijk E, \& Van Knippenberg D. (1996). Buying and selling exchange goods: loss aversion and the endowment effect. Journal of Economic Psychology, 17, 517-524.

van Someren, M.W., Barnard, Y.F., \& Sandberg, J.A. C. (1994). The think aloud method. London: Academic Press.

Voeth, M., \& Herbst, U. (2006). Supply-chain pricing - a new perspective on pricing in industrial markets. Industrial Marketing Management, 35, 83-90.

Vonk, R. (1999). Effects of outcome dependency on correspondence bias. Personality and Social Psychology Bulletin, 25, 382-389.

Webster, F.E., Jr., \& Wind, Y. (1972). A general model for understanding organizational buying behavior. Journal of Marketing, 36, 12-9.

Weick, K.E. (1979). The social psychology of organizing. Reading, MA: Addison-Wesley.

Williamson, O.E. (1975). Markets and Hierarchies. New York: Free Press.

Wilson, E. J. (1984). A case study of repeat buying for a commodity. Industrial Marketing Management, 13, 195-200.

Wilson, E.J., McMurrian, R.C., \& Woodside, A.G. (2001). How buyers frame problems: revisited, Psychology and Marketing, 18, 617-655.

Woodside, A. G., \& Wilson, E. J. (2000). Constructing thick descriptions of marketers' and buyers' decision processes in business-to-business relationships. Journal of Business \& Industrial Marketing, 15, 354-369. 
Figure 1

A Conceptual Framework for Understanding the Interpretation of Context on Pricing Strategy

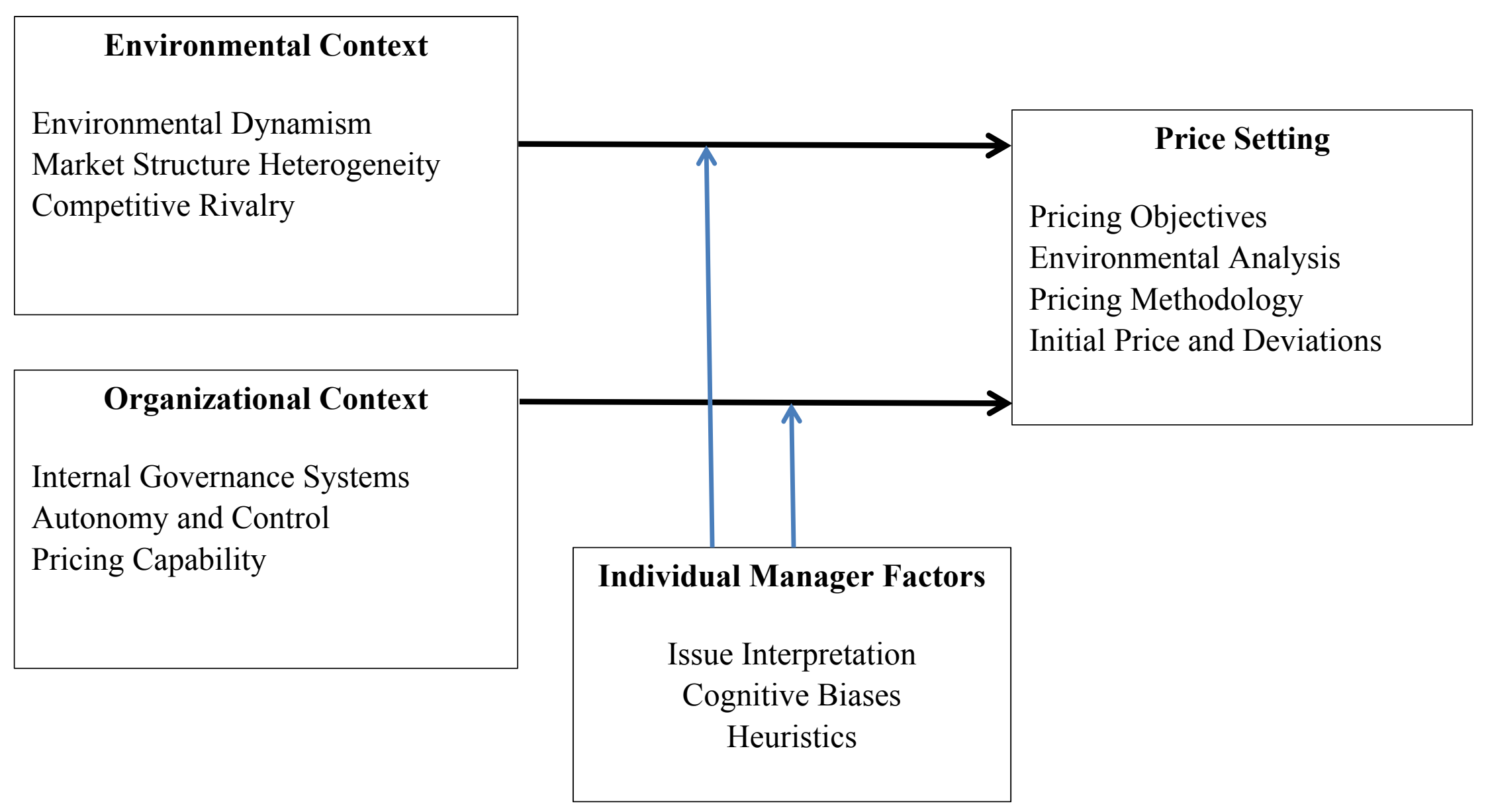


Table 1: Putative Behavioral Biases and Implications for Pricing

\begin{tabular}{|c|c|c|c|}
\hline Pricing Stage & Putative Behavioral Biases & Implications for Pricing & $\begin{array}{l}\text { Sample Research on Reducing bias } \\
\text { in Pricing }\end{array}$ \\
\hline $\begin{array}{l}\text { Selecting the } \\
\text { Pricing Objective }\end{array}$ & $\begin{array}{l}\text { Loss Aversion: Managers may choose less } \\
\text { risky objectives to avoid losses (Tversky \& } \\
\text { Kahneman 1991; van Dijk \& van Knipenberg } \\
\text { 1996) } \\
\text { Good Enough Returns: Managers may satisfy } \\
\text { on their objective rather than optimize } \\
\text { (Kahneman \& Tversky 1979). } \\
\text { Endowment Effect: What is owned is } \\
\text { preferred to what can be obtained (Thaler } \\
\text { 1980) }\end{array}$ & $\begin{array}{l}\text { Inappropriate pricing setting } \\
\text { (considered safe) may be chosen in } \\
\text { pricing. For example, instead of a } \\
\text { product leadership strategy for quality } \\
\text { products, managers may undervalue } \\
\text { quality and choose a safer objective } \\
\text { (Tellis \& Johnson 2007). Managers } \\
\text { may be more focused on current } \\
\text { markets rather than pursue strategies of } \\
\text { gaining customers from competitors } \\
\text { through pricing. }\end{array}$ & $\begin{array}{l}\text { Perspective Taking. Taking the } \\
\text { perspective of others or thinking of } \\
\text { decisions as making them for others } \\
\text { reduces biases (c.f., Andersson, Holm, } \\
\text { Tyran \& Wengström (2013). } \\
\text { Adaptive Learning - learn through } \\
\text { feedback on previous decisions (Al- } \\
\text { Najjar, Baliga \& Besanko, 2008). }\end{array}$ \\
\hline $\begin{array}{l}\text { Estimating and } \\
\text { Determining } \\
\text { Demand }\end{array}$ & $\begin{array}{l}\text { Overconfidence: Managers may believe } \\
\text { strongly in their own knowledge and } \\
\text { information (Barber \& Odean 1999; Daniel \& } \\
\text { Titman 1999; Coval \& Shumway 2005) } \\
\text { Correspondence Bias: Errors are made when } \\
\text { inferring dispositions from behaviors of } \\
\text { customers (Vonk 1999) } \\
\text { Representativeness Bias: Desirable qualities } \\
\text { are overvalued (De Bondt \& Thaler 1985) }\end{array}$ & $\begin{array}{l}\text { Managers may incorrectly estimate } \\
\text { demand for their products. Current } \\
\text { consumers and markets may be valued } \\
\text { more in order to maintain a positive } \\
\text { self-image (Beggan 1992). } \\
\text { Managers may wrongly infer } \\
\text { purchasing managers' preferences and } \\
\text { intentions. } \\
\text { Managers may assume that good } \\
\text { companies are also good customers. }\end{array}$ & $\begin{array}{l}\text { Information sharing within the firm, } \\
\text { outside the firm (suppliers) and the use } \\
\text { of industry experts reduces demand } \\
\text { determination biases (c.f., Ozer \& } \\
\text { Zheng, 2012, p5). } \\
\text { Adaptive Learning (as above). }\end{array}$ \\
\hline $\begin{array}{l}\text { Estimating and } \\
\text { Determining Costs }\end{array}$ & $\begin{array}{l}\text { Sunk Costs Fallacy: Past costs and } \\
\text { investments influence future choices (Arkes \& } \\
\text { Blumer 1985) }\end{array}$ & $\begin{array}{l}\text { Managers may be focused on the } \\
\text { recovery of past investments and } \\
\text { include these in costs for pricing. } \\
\text { Also, the purchase of an input under a } \\
\text { long-term contract may be treated as a } \\
\text { sunk cost rather than something that } \\
\text { can be resold (Al-Najjar et al. 2008) }\end{array}$ & $\begin{array}{l}\text { Mindfulness - Mindfulness can be } \\
\text { increased by meditation that reduces } \\
\text { the sunk cost bias (Hafenbrack, Kinias, } \\
\text { \& Barsade 2013). }\end{array}$ \\
\hline $\begin{array}{l}\text { Competitive } \\
\text { Analysis of Cost, } \\
\text { Price Tactics, and }\end{array}$ & $\begin{array}{l}\text { Anchoring and Adjustment: Adjustments are } \\
\text { made from some known information so as to } \\
\text { arrive at values that are acceptable. However, }\end{array}$ & $\begin{array}{l}\text { Despite adjustments, managers' } \\
\text { perceptions of competitive actions may } \\
\text { not change much. Therefore, prices }\end{array}$ & $\begin{array}{l}\text { Feedback mechanisms on pricing } \\
\text { decisions reduces biases (Al-Najjar, } \\
\text { Baliga \& Besanko, 2008; Ozer \& }\end{array}$ \\
\hline
\end{tabular}




\begin{tabular}{|l|l|l|l|}
\hline Discounts/Rebates & $\begin{array}{l}\text { the final values are close to the anchor } \\
\text { (Tversky \& Kahneman 1974) }\end{array}$ & $\begin{array}{l}\text { may change despite new competitive } \\
\text { information. }\end{array}$ & $\begin{array}{l}\text { Zheng, 2012). Use of Decision } \\
\text { Support Systems reduces biases } \\
\text { (George, Duffy \& Ahuja 2000) }\end{array}$ \\
\hline $\begin{array}{l}\text { Determining a } \\
\text { Pricing } \\
\text { Methodology }\end{array}$ & $\begin{array}{l}\text { Familiarity Bias: Managers may prefer tools } \\
\text { and techniques that they know more than ones } \\
\text { that are more appropriate (Huberman 2001) }\end{array}$ & $\begin{array}{l}\text { Familiar and currently used cost-plus } \\
\text { approaches may be used even though } \\
\text { the situation may call for other } \\
\text { methods. }\end{array}$ & $\begin{array}{l}\text { Improving understanding of managers' } \\
\text { information environment and how } \\
\text { uncertainty should be dealt with } \\
\text { (Urbany, 2001). Use probabilities to } \\
\text { make decisions (Fox \& Levav 2000). }\end{array}$ \\
\hline $\begin{array}{l}\text { Setting the Price } \\
\text { \& Deviating from } \\
\text { List Prices }\end{array}$ & $\begin{array}{l}\text { Status Quo Bias: Doing nothing when faced } \\
\text { with choices (Samuelson \& Zeckhauser 1988) }\end{array}$ & $\begin{array}{l}\text { Managers rely on current approach to } \\
\text { price setting and also do not deviate } \\
\text { from list prices even when the situation } \\
\text { changes. }\end{array}$ & $\begin{array}{l}\text { Revisit the pricing decision and create } \\
\text { a new decision tree, highlighting } \\
\text { customer preferences. Match data with } \\
\text { external customer data. }\end{array}$ \\
\hline
\end{tabular}

